\title{
LINKING FLORAL BIODIVERSITY WITH NITROGEN AND CARBON TRANSLOCATIONS IN SEMI-NATURAL GRASSLANDS IN LITHUANIA
}

\author{
SAULIUS MARCINKONIS ${ }^{1,3^{*}}$, BIRUTÉ KARPAVIČIENE ${ }^{2}$, MICHAEL A. FULLEN $^{4}$ \\ ${ }^{1}$ Vilniaus kolegija, Saltoniškių 58, LT-08105 Vilnius, Lithuania; e-mail: s.marcinkonis@viko.lt \\ ${ }^{2}$ Institute of Botany Nature Research Centre, Žaliųjų Ežerų g. 49, LT-08406 Vilnius, Lithuania \\ ${ }^{3}$ Voke branch of the Lithuanian Research Centre for Agriculture and Forestry, Žalioji a. 2, Trakų Vokè, LT-02232 \\ Vilnius, Lithuania \\ ${ }^{4}$ Faculty of Science and Engineering, The University of Wolverhampton, Wolverhampton WV1 1LY, UK
}

${ }^{\star}$ Author for correspondence

Abstract

Marcinkonis S., Karpavičienė B., Fullen M.A.: Linking floral biodiversity with nitrogen and carbon translocations in semi-natural grasslands in Lithuania. Ekológia (Bratislava), Vol. 34, No. 2, p. 137-146, 2015.

The aim of the present study is to evaluate the long-term effects of long-term piggery effluent application on semi-natural grassland ecotop-phytotop changes (above- and below-ground phytomass production, and carbon and nitrogen allocation in grassland communities) in relation to changes (or variability) in topsoil properties. Analysis of phytomass distribution in piggery effluent irrigated grassland communities showed that dry biomass yield varied from $1.7-5.3 \mathrm{t} \mathrm{ha}^{-1}$. Variability in soil and plant cover created a unique and highly unpredictable site specific system, where long-term anthropogenic influences established successor communities with specific characteristics of above- and below-ground biomass distribution. These characteristics depend more on grassland communities than on soil chemical properties. Families of grasses (Poaceae) dominated the surveyed communities and accumulated most carbon and least nitrogen, while legumes accumulated most nitrogen and lignin and least carbon. Carbon concentrations in above-ground biomass had minor variations, while accumulation of nitrogen was strongly influenced by species diversity $(\mathrm{r}=0.94, \mathrm{n}=10, \mathrm{p}<0.001)$ and production of above-ground biomass.

Key words: piggery effluent, phytomass, Poaceae, Fabaceae, soil humus.

\section{Introduction}

The main parts of meadows, known as multi-plant community of various perennial species, have different morphological and ecological characteristics, as well as different nutritional and economic values. Semi-natural grasslands provide, especially wide range of habitats supporting rich biological diversity. Botanical composition diversity within perennial grassland often leads to ecosystem stability and enhances resistance to disturbance (Waide et al., 1999). Summarised results from relevant studies demonstrated that increasing diversity can lead to greater biomass in various ecosystems (Cardinale et al., 2007). The German biodiversity 
exploratory project found declining multidiversity with increasing land use intensity among grasslands, particularly for rarer species and above-ground organisms, whereas common species and below-ground groups were less sensitive (Allan et al., 2014). And vice versa, specific management, such as setting aside non-fertilised strips with further management (e.g. annual cutting and removal of plant material), contributed to increased plant species richness (Hovd, 2008). However, natural grasslands established on former arable lands (generated from fallow systems) were much less productive compared to sown grasslands during the first decade of land use conversion (Marcinkonis, 2007).

Ecologists and biogeographers have identified grassland (meadows and pastures) as land cover in the area of conflict between agriculture and conservation, where intensification of land use is a major threat to grassland biodiversity (Sulzer et al., 2013; Allan et al., 2014). There has been extensive reduction of semi-natural grasslands during the past 100 years in Sweden (approximately 90\%) and 97-99\% reduction in Finland and England (Öster, 2006). Similar reductions of semi-natural and natural grasslands have been reported in Lithuania. However, differences in definitions among various specialists have led to various estimates of their total area, from an estimated 42,000 ha of such grasslands per the Lithuanian grassland inventory in 2002-2005 (Grasslands of Lithuania, 2006), to others suggesting $\leq 168,000$ ha (Redman, 2002). The dramatic loss of natural and semi-natural grasslands in Europe is, especially linked to increased nutrient loads during the last century (Pärtel et al., 2005).

Declines in species richness due to fertilisation are typically rapid and associated with increases in above-ground production (Dickson, Gross, 2013). Nutrient enhancements depress diversity by affecting species interactions, species richness declines and several fast-growing plant species eliminate less competitive ones by outcompeting for resources, such as light (Plantureux et al., 2005). Application of farm manures causes enrichment in nutrients and influences other important factors (play roles) including differences in nutrient availability, richness and ratios, and stimulation of microbiological activity. The application of farm factory waste in herbaceous plant communities does not necessarily target only an improvement in productivity and yield quality, but also to utilisation of large quantities of farm factory wastes, including liquid manures. Our previous studies carried out in slurry-fertilised meadows demonstrated that low-diversity grasslands came into existence as a result of the long-term anthropogenic impact (Karpavičienė, Marcinkonis, 2009). The aim of the present study is to explore links between floral diversity of grassland communities and nitrogen $(\mathrm{N})$ and carbon (C) translocations affected by long-term liquid manure applications.

Agri-environmental schemes governed by European Union regulations are important instruments in combating the decline of semi-natural grasslands, but appear to be too inflexible to take spatial differences in conservation values into account (Arponen et al., 2013). There is evidence that specific chemical soil characteristics may be required to restore or maintain species-rich grasslands (Janssens et al., 1998), because spatial heterogeneity in soil resources affects the distribution of plant species in grasslands (Eilts et al., 2011). In Lithuania, the dependence of landscape components upon geological substrata was found to be very strong in the middle course of the river, Nemunas and the Neris low-course plateau (Česnulevičius et al., 2003).

Experimental procedures 
Site geography and climate: Factory farm slurry irrigation fields (total area approximately 200 ha) were selected as a study site. The Zelve site $\left(54^{\circ} 49^{\prime} 07^{\prime \prime}-54^{\circ} 49^{\prime} 31^{\prime \prime} \mathrm{N}, 24^{\circ} 46^{\prime} 33^{\prime \prime}-\right.$ $24^{\circ} 45^{\prime} 46^{\prime \prime} \mathrm{E}$ ) is located in the middle Lithuanian lowlands, in the basin of the river, Neris and belongs to the Nemoral environmental zone. Climatic conditions are characterised by the vegetation growth season $\left(\geq 10^{\circ} \mathrm{C}\right)$ lasting on average $183-191$ days per year, and +6.2 ${ }^{\circ} \mathrm{C}$ mean annual air temperature and $661 \mathrm{~mm}$ mean annual precipitation. The site elevation range is $113-123 \mathrm{~m}$ above sea level. The topography of the site was plain relief that varied with numerous submarine thermokarst origin irregular surfaces of marshy hollows approximately 4-5 $\mathrm{m}$ below the surrounding terrain.

Site soils and management: The territory is dominated by glacio-lacustrine sediments. Soils are Gleyic Podzols, Gleyic Luvisols and Luvisols, Dystric Gleysols and Calcari-Mollic Gleysols (FAO classification). Soil properties are spatially highly variable, with $\mathrm{pH}$ varying from 4.7-6.8, and carbon-to-nitrogen ratios from 4.5-12.4, (where low values of ratio are) corresponding to areas of intensive decomposition of organic matter. Eco-chemical characteristics of the site are reported in Table 1.

T a b l e 1. Site ecological and soil chemical characteristics ( $n=33$ samples).

\begin{tabular}{|c|c|c|c|c|c|c|}
\hline & $\begin{array}{c}\text { Elevation } \\
(\mathrm{m})\end{array}$ & $\begin{array}{c}\text { Braun-Blanquet } \\
\text { cover-abundance } \\
(\%)\end{array}$ & $\mathrm{pH}(1 \mathrm{M} \mathrm{KCl})$ & $\begin{array}{c}\text { Carbon to nitrogen } \\
\text { ratio }\end{array}$ & \multicolumn{2}{|c|}{ Soil available } \\
\cline { 5 - 7 } & & 82 & 5.94 & 9.1 & $\mathrm{P}_{2} \mathrm{O}_{5}$ & $\mathrm{~K}_{2} \mathrm{O}$ \\
$\left(\mathrm{mg} \mathrm{kg}^{-1}\right)$ & 278 & 195 \\
$\left(\mathrm{mg} \mathrm{kg}^{-1}\right)$
\end{tabular}

Note: ${ }^{\star}$ SEM - standard error of the mean

Farm factory pig excrements (faeces and urine) are collected in ponds from where they are spread throughout the field using field irrigation system in fixed short-term cycles during the months of April, May, July and August. Small quantities are spread during the month of June. Average annual load of slurry is approximately $300 \mathrm{~m}^{3} \mathrm{ha}^{-1}$. The livestock density is 2.64-2.86 animal units per ha. Land of irrigation fields idle for last 20 years, cultural lawn in recent years occasionally grazed and mown. Chemical characteristics of liquid manure vary slightly, macronutrients concentrations ranged from $0.45-0.49 \mathrm{~m}^{3} \mathrm{~kg}^{-1}$ total $\mathrm{N}(\mathrm{tN} \%)$, $0.02-0.03 \mathrm{~m}^{3} \mathrm{~kg}^{-1}$ total $\mathrm{P}$ and $0.45-0.48 \mathrm{~m}^{3} \mathrm{~kg}^{-1}$ total $\mathrm{K}$.

Field measurements, sampling and analysis: Soils were sampled from representative 33 micro-plots (approximately $10-15 \mathrm{~m}^{2}$ ). Plots were pre-selected based on their morphological site characteristics. Plots were examined in detail and the main soil and vegetation characteristics determined. For the second phase, 10 sampling areas were selected for collecting soil and plant samples and in situ measurements (Fig. 1). Sampling from selected points was made in early June (2009), above-ground biomass was sampled from square plots measuring $1 \mathrm{~m}^{2}$ and $0.01 \mathrm{~m}^{3}(0.2 \times 0.2 \times 0.25 \mathrm{~m})$ soil volume excavated, and samples were washed to determine underground plant mass. At each sampling site, a composite soil sample of approximately $0.5 \mathrm{~kg}$ (using auger at $0-20 \mathrm{~cm}$ depth) was collected randomly from a $50-100 \mathrm{~m}^{2}$ area. Soil samples were 


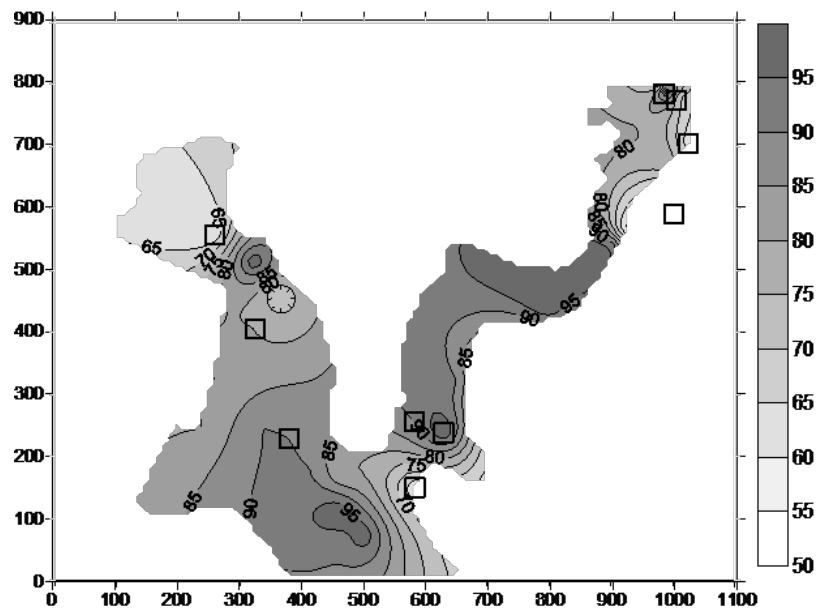

Fig. 1. Contour map of plant cover-abundance at the Zelve study site (coordinates in metres on $\mathrm{X}$ and $\mathrm{Y}$ axis) with indicated sampling plots (in rectangular frames). tested for composition of humus (by the Ponomariova Plotnikova-modified Tyurin method), soil organic C content (SOC\%) (by dry combustion of samples of $900^{\circ} \mathrm{C}$ ) and $\mathrm{tN} \%$ by the Kjeldahl method. Biomass samples were collected from the same sampling areas to determine botanical composition and for subsequent laboratory analyses. Vegetation samples were analysed as follows: C (dry combustion method), $\quad \mathrm{tN} \%$ (Kjeldahl method), and lignin (GOST 26177-84 weighing method, washed in $72 \% \mathrm{H}_{2} \mathrm{SO}_{4}$ ).

Data processing: Data from chemical analyses were stored in a dataset according to its geographical co-ordinates. Various statistical analyses were used to study the nature and magnitude of variability in the datasets. Several clusterisation methods were used: single connection method, a full coupling method and the Ward method. Descriptive statistics (mean, median, minimum, maximum, standard deviation, kurtosis and skewness) were performed using routine methods. Impact of soil properties on vegetation cover and variability was assessed using correlation-regression analysis (Minitab 16).

\section{Results and discussion}

Phytomass distribution. According to plant taxonomy, the largest part of study sites comprised of ruderal and semi-ruderal plant communities and only negligible parts of plant

$\mathrm{T}$ a b l e 2. Variation of biomass in grassland irrigated with liquid manure $(\mathrm{n}=10$ samples).

\begin{tabular}{|l|c|c|c|c|c|}
\hline Parameter & Mean \pm SEM & Min & Max & ${ }^{\star}$ SD & Coefficient of variation \% \\
\hline Above-ground dry mass, $\left(\mathrm{g} \mathrm{m}^{-2}\right)$ & $346.4 \pm 41.2$ & 167.5 & 525.3 & 130.3 & 11.9 \\
\hline Poaceae dry mass $\left(\mathrm{g} \mathrm{m}^{-2}\right)$ & $57.7 \pm 12.8$ & 0 & 131.3 & 40.6 & 22.3 \\
\hline Poaceae dry mass $(\%)$ & $68.0 \pm 12.3$ & 0 & 100 & 39.0 & 18.9 \\
\hline Fabaceae dry mass $\left(\mathrm{g} \mathrm{m}^{-2}\right)$ & $4.1 \pm 2.5$ & 0 & 26.1 & 8.0 & 62.4 \\
\hline Fabaceae dry mass (\%) & $4.0 \pm 2.0$ & 0 & 20.4 & 6.4 & 50.6 \\
\hline Forbs dry mass $\left(\mathrm{g} \mathrm{m}^{-2}\right)$ & $24.9 \pm 11.0$ & 0 & 102.4 & 34.8 & 44.2 \\
\hline Forbs dry mass $(\%)$ & $28.0 \pm 12.5$ & 0 & 100 & 39.4 & 44.6 \\
\hline Below-ground dry mass $\left(\mathrm{g} \mathrm{m}^{-2}\right)$ & $889.9 \pm 159.0$ & 627.0 & 1176.3 & 275.4 & 30.9 \\
\hline $\begin{array}{l}\text { Ratio of above- and below-ground } \\
\text { biomass }\end{array}$ & $0.39 \pm 0.10$ & 0.19 & 0.52 & 0.17 & 43.6 \\
\hline
\end{tabular}

Note: ${ }^{\star} \mathrm{SD}$ - standard deviation 
communities were fertile meadows. Variability in soil and plant cover is creating a unique and highly unpredictable site-specific system. Results revealed that the green above-ground biomass at survey sites varied by a broad range [640-2640 $\mathrm{g} \mathrm{m}^{-2}$, coefficient of variation (CV) 44.8\%] (Table 2). This reflects the high heterogeneity of vegetation cover, topography and soil diversity at the sites. Dry

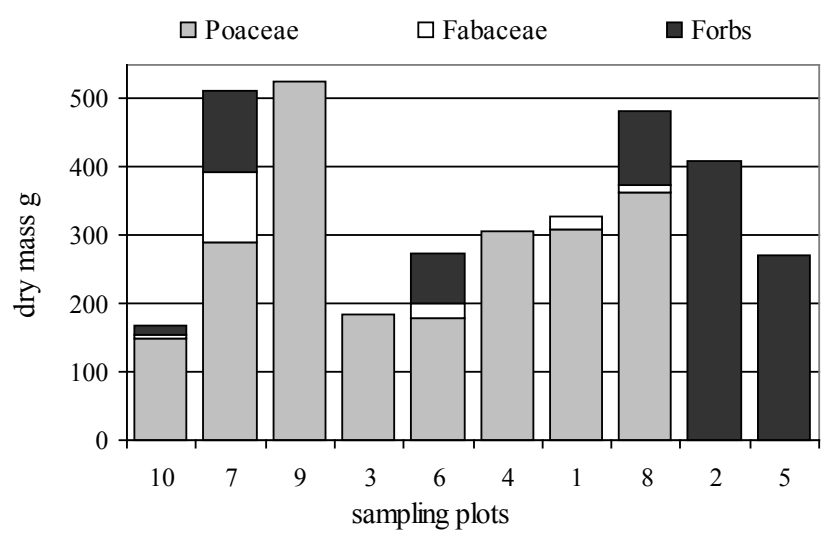

Fig. 2. Distribution and floristic composition of dry above-ground biomass [sampling plots ranked by SOC $\%$ from low (0.7\%) to high $(6.8 \%)$ ]. weight of biomass had less variation [167.48-525.28 $\mathrm{g} \mathrm{m}^{-2}, \mathrm{CV}=11.9 \%$ ], because high green biomass values were recorded in wet areas. The fluctuation of floristic composition depends on grassland type and natural grasslands have stable productivity of more than sown grassland, as reported from other studies in Lithuania (Klimas, Baležentienè, 2008). Biomass varied widely with respect to the floristic composition of samples. Some $50 \%$ of the collected samples had only one group of botanical plants, $30 \%$ of biomass samples consisted only of Poaceae, and $20 \%$ only forbs (Fig. 2). Poaceae dominated in almost all samples, and their mean weight was $68 \%$ of the total weight of the collected biomass (Table 2). The largest part of biomass samples were couch grass (Elytrigia repens $\mathrm{L}$. Nevski). Same shift in pasture grasses resulting in a predominance of couch grass was found on the site of liquid pig manure application (Wilson et al., 2009).

Families of legumes (Fabaceae) are among the most important components of grassland phytotop. Even though legumes were found in $50 \%$ of the biomass samples, their dry biomass ranged from $2.5-20.4 \%$ and represented a small proportion of the grassland plants (mean only $4 \%$ ) (Table 2 ). Forbs were dominated by stinging nettle (Urtica dioica L.). This group of plants had approximately $28 \%$ of the total weight of dry above-ground biomass. Gustavsson (2007) observed strong correlations between historical agricultural practices and current plant diversity patterns and claimed that current diversity patterns are thus a result of historical and current land use in combination. We hypothesise that the unequal distribution of above-ground biomass in the study area belonged to different environmental conditions, in particular of soil organic matter (SOM) properties, which in turn corresponded to different hydrological conditions.

Soil variability was poorly reflected in vegetation cover; correlation analysis did not identify statistically significant direct or indirect associations between the green or dry mass and various indicators of soil humus status (Table 3). It is likely that nutrient uptake and biomass accumulation were influenced by terrain diversity and have not been limited by soil moisture regime, fully satisfied by rainfall in automorphic areas of the site. Grassland dry matter yield responds positively to rainfall (Zableckienè, Butkutè, 2006; Daugèlienè, Butkute், 2007). Vari- 
$\mathrm{T}$ a b l e 3. Correlation matrix of biomass indices with soil chemical properties and floristic composition $\left({ }^{*} \mathrm{p}<0.05\right.$; $\left.{ }^{* *} \mathrm{p}<0.01 ; \mathrm{n}=10\right)$.

\begin{tabular}{|l|c|c|c|c|c|}
\hline Parameter & Biomass $\left(\mathrm{g} \mathrm{m}^{-2}\right)$ & \multicolumn{4}{|c|}{ Dry mass $\left(\mathrm{g} \mathrm{m}^{-2}\right)$} \\
\hline & & Total & Poaceae & Fabaceae & Others \\
\hline Humus (\%) & 0.21 & -0.15 & -0.52 & -0.33 & 0.54 \\
\hline Humic acids (\%) & 0.14 & -0.19 & -0.45 & -0.35 & 0.43 \\
\hline Fulvic acids (\%) & 0.20 & -0.07 & -0.40 & -0.32 & 0.47 \\
\hline Ratio of humic and fulvic acids & -0.09 & -0.49 & -0.39 & -0.44 & 0.10 \\
\hline Organic C (\%) & 0.18 & -0.44 & $-0.71^{\star}$ & -0.47 & 0.58 \\
\hline Total N (\%) & 0.21 & -0.42 & $-0.75^{\star}$ & -0.46 & $0.64^{\star}$ \\
\hline C/N ratio & 0.05 & -0.54 & -0.45 & -0.61 & 0.24 \\
\hline Number of species & 0.16 & $0.64^{*}$ & 0.46 & $0.91^{* *}$ & -0.15 \\
\hline
\end{tabular}

$\mathrm{T}$ a b $1 \mathrm{e}$ 4. Allocation of $\mathrm{C}, \mathrm{N}$ and lignin (into above-ground biomass) in relation to floristic composition.

\begin{tabular}{|c|c|c|c|c|c|}
\hline Parameter & Mean+SEM & Min & $\operatorname{Max}$ & $\mathrm{SD}$ & Coefficient of variation $\%$ \\
\hline \multicolumn{6}{|c|}{ Carbon } \\
\hline In Poaceae (\%) & $38.6 \pm 1.69$ & 28.47 & 43.26 & 4.77 & 12.4 \\
\hline In Fabaceae (\%) & $34.8 \pm 4.07$ & 30.77 & 38.91 & 5.76 & 16.5 \\
\hline In forbs (\%) & $38.5 \pm 1.18$ & 35.37 & 41.06 & 2.35 & 6.11 \\
\hline Total C $\left(\mathrm{t} \mathrm{ha}^{-1}\right)$ & $1.45 \pm 0.19$ & 0.80 & 2.15 & 0.50 & 34.5 \\
\hline \multicolumn{6}{|c|}{ Nitrogen } \\
\hline In Poaceae (\%) & $2.0 \pm 0.09$ & 1.69 & 2.45 & 0.26 & 13.3 \\
\hline In Fabaceae (\%) & $3.2 \pm 0.33$ & 2.90 & 3.56 & 0.47 & 14.6 \\
\hline In forbs (\%) & $2.5 \pm 0.25$ & 2.27 & 3.27 & 0.49 & 19.3 \\
\hline Total N $\left(\mathrm{t} \mathrm{ha}^{-1}\right)$ & $84.1 \pm 12.9$ & 41.8 & 133.9 & 34.0 & 40.4 \\
\hline \multicolumn{6}{|c|}{ Lignin } \\
\hline In Poaceae (\%) & $7.5 \pm 0.18$ & 6.91 & 8.16 & 0.50 & 6.7 \\
\hline In Fabaceae (\%) & $13.0 \pm 0.75$ & 12.20 & 13.69 & 1.05 & 8.1 \\
\hline In forbs $(\%)$ & $8.2 \pm 0.12$ & 7.89 & 8.41 & 0.23 & 2.8 \\
\hline Total lignin $\left(\mathrm{t} \mathrm{ha}^{-1}\right)$ & $293.8 \pm 45.2$ & 140.6 & 464.6 & 119.6 & 40.7 \\
\hline
\end{tabular}

ous species found to be controlled by interactions of soil fertility and management, such as couch grass, dominated in places used occasionally for hay production, nettles prevailed in a few locations where sedimentation of organic waste was most concentrated relating to landscape contours. Studies in semi-natural meadows in the UK found that mineralisable $\mathrm{N}$ was the most important soil characteristic in semi-natural sites; the more $\mathrm{N}$ the soil contained, the fewer were the species characteristic of traditional meadows (McCrea et al., 2004). We found a strong association between total soil $\mathrm{N}$ and dry mass of Poaceae $(\mathrm{r}=0.75, \mathrm{n}=10, \mathrm{p}$ $<0.05)$.

Given that fertilisation increases grassland productivity, it is expected that long-term irrigation with liquid manure continuously increases biomass, especially above ground in herbaceous plant communities. However, it was not confirmed comparing our obtained firstcut (June) data with data references of extensively used perennial grassland. Dry biomass yield of the studied site was from 1.7-5.3 $\mathrm{t} \mathrm{ha}^{-1}$ dry biomass, limits set by Sendžikaitè and 
$\mathrm{T}$ a b l e 5. Correlation matrix of above-ground biomass N, C and lignin concentrations with floristic composition and soil chemical properties $\left({ }^{*} \mathrm{p}<0.05 ;{ }^{* *} \mathrm{p}<0.01 ; \mathrm{n}=10\right)$.

\begin{tabular}{|l|c|c|c|}
\hline Parameter & $\mathrm{N}\left(\mathrm{t} \mathrm{ha}^{-1}\right)$ & $\mathrm{C}\left(\mathrm{t} \mathrm{ha}^{-1}\right)$ & Lignin $\left(\mathrm{t} \mathrm{ha}^{-1}\right)$ \\
\hline Humus (\%) & -0.20 & -0.43 & -0.40 \\
\hline Humic acids (\%) & -0.32 & -0.52 & -0.50 \\
\hline Fulvic acids (\%) & -0.19 & -0.34 & -0.34 \\
\hline Ratio of humic and fulvic acids & -0.62 & $-0.92^{* *}$ & $-0.93^{* *}$ \\
\hline Dry mass ( $\left.\mathrm{t} \mathrm{ha}^{-1}\right)$ & $0.83^{*}$ & $0.99^{* *}$ & $0.98^{* *}$ \\
\hline Poaceae (\%) & -0.46 & -0.04 & -0.15 \\
\hline Fabaceae (\%) & 0.43 & 0.49 & 0.57 \\
\hline Forbs (\%) & 0.38 & -0.04 & 0.05 \\
\hline Number of species & $0.94^{* *}$ & 0.79 & $0.86^{*}$ \\
\hline
\end{tabular}

Pencekauskienè (2003) referenced extensively used perennial grassland harvests ranging from approximately $1-7 \mathrm{tha}^{-1}$.

The reason for this may be due to reduced grassland species diversity after long-term sewage irrigation (Karpavičienè, Marcinkonis, 2009), because direct relationships exist between species diversity and the productivity of grassland communities (Bullock et al., 2001; Tilman et al., 2001; Cardinale et al., 2007; Flombaum, Sala, 2008). Although temporal heterogeneity is a well-accepted driver of grassland biodiversity, effects of inter-annual variation in land-use intensity have not been fully addressed (Allan et al., 2014). Correlation analysis demonstrated an association between the number of species and dry matter yield $(\mathrm{r}=0.64, \mathrm{n}$ $=10, \mathrm{p}<0.05$; Table 3 ). Thus, it appears that the long-term sewage irrigation of meadows not only reduces diversity of the herbaceous plant community, but also affects the formation of above-ground biomass. Some studies indicate that low-input management does not necessarily result in sward productivity losses (Bošnjak et al., 2006).

Mean plant below-ground mass in the $0-25 \mathrm{~cm}$ layer of a $1 \mathrm{~m}^{2}$ area of the sample plots was $889.9 \mathrm{~g}$ and about three-times the mass of the surface (Table 2). In areas with regular use of organic fertilisers, fertilised meadows declined in below-ground biomass and increased above-ground biomass as expected, as improved $\mathrm{N}$ supply promotes greater above-ground resources (Bloom et al., 1985; Schläpfer, Ryser, 1996; Maire et al., 2009). However, the results indicate that the above-/below-ground mass ratio was significantly lower than that of perennial grasslands reported in the literature (Bray, 1963; Maire et al., 2009). This difference may be explained by floral composition, whereas the studied plant communities were dominated by ordinary couch grass, which is characterised by perennial rhizomes or adverse soil moisture regime, as more below-ground biomass was found in higher elevation areas, where because of drier growing conditions, more resources were allocated to above-ground plants (Pace et al., 1999; Liu et al., 2004).

Phytomass quality. The results of $\mathrm{C}$ and $\mathrm{N}$ accumulation in plants indicated that the distribution of elements in the study area depended on floristic groups of plant communities. Most $\mathrm{C}(38.6 \%)$ and least $\mathrm{N}(2.0 \%)$ were gained by Poaceae. Fabaceae and forbs were characterised by the highest $\mathrm{N}(3.2 \%)$ and the lowest $\mathrm{C}(34.8 \%)$ concentrations (Table 4$)$. $\mathrm{N}$ had widest variation in the above-ground biomass of different botanical groups of plants (CV 13.3-19.3\%). 
The $\mathrm{N}$ content in dry biomass often indicates $\mathrm{N}$ supply for plant requirements (Kadžiulienė, Kadžiulis, 2007). Given that the samples were collected at the most of the soil chemical composition contrasting points can be expected that such variation will be determined by environmental factors. Correlation analysis showed that the strongest correlation was between the above-ground part of the accumulated $\mathrm{C}$ and lignin content and the soil humus and ratio of humic and fulvic acids, respectively $(\mathrm{r}=-0.92, \mathrm{r}=-0.93 ; \mathrm{p}<0.05$; Table 5$)$, although the correlations with either the humic or with fulvic acids were not significant. Poaceae family plants grown in combination with Fabaceae accumulated more $\mathrm{N}$ in above-ground biomass compared to those grown on their own culture (Elgersma et al., 2000; Gastal, Lemaire, 2002). Data of our survey did not correspond to these findings. The correlation between the amount of $\mathrm{N}$ accumulated in Poaceae and Fabaceae was weak and insignificant $(\mathrm{r}=-0.12, \mathrm{n}=10, \mathrm{p}=0.78)$. The reason why such relationships are poorly visible is because population of Fabaceae family plants were fragmentary in surveyed communities, and the above-ground biomass accounts for only $4 \%$ of the total phytomass. It is likely that for the same reason, the correlation between $\mathrm{N}$ accumulation in plant biomass and proportion of Fabaceae was not significant $(\mathrm{r}=0.43, \mathrm{p}=$ 0.33; Table 5).

Cumulative amount of $\mathrm{N}$ in the above-ground part of plant communities mostly depended on species diversity $(\mathrm{r}=0.94, \mathrm{n}=10, \mathrm{p}<0.05)$ and total above-ground dry biomass $(\mathrm{r}=0.83, \mathrm{n}=10, \mathrm{p}$ $<0.05$ ). If $\mathrm{N}$ availability is sufficient, the accumulated $\mathrm{N}$ content is very closely related to biomass accumulation and growth rate (Gastal, Lemaire, 2002). Also, with the hydrothermal regime, better access to water guarantees much more efficient $\mathrm{N}$ uptake of by plants (Mills et al., 2009).

Although in above-ground biomass, accumulated $\mathrm{C}$ varied depending on the botanical composition and sampling sites, the total accumulated $\mathrm{C}$ had a particularly strong correlation with total above-ground biomass (Table 5). The main reason for this is that $\mathrm{C}$ concentrations of above-ground biomass were fairly constant $(\mathrm{CV}=5.4 \%)$ and varied in relatively narrow limits (36.4-41.1\%) in surveyed communities.

\section{Conclusion}

Studies conclude that liquid manure irrigated grassland site variability in soil and plant cover is creating a unique and highly unpredictable site-specific system. The green above-ground biomass varied by a broad range (6.40-26.40 $\left.\mathrm{t} \mathrm{ha}^{-1}\right)$, while the dry weight of biomass had less variation $\left(1.67-5.25 \mathrm{t} \mathrm{ha}^{-1}\right)$. Mean plant below-ground mass was about three-times the mass of the surface.

Domination of various species was controlled by the interaction of soil fertility and management. For instance, couch grass dominated in places used occasionally for hay production, while nettles prevailed in a few locations where sedimentation of organic waste was most concentrated in relation to landscape contours.

Biomass was dominated by Poaceae, with a mean weight of $68 \%$ of the total weight of the collected biomass. The largest part of biomass samples was common couch. Legumes represented a small proportion of the grassland plants (mean only 4\%).

Results showed that different plant families in above-ground biomass, on average, accumulated $2.0-3.2 \% \mathrm{~N}, 34.8-38.6 \% \mathrm{C}, 7.5-13.0 \%$ lignin; this was strongly related to floral diversity. Concentration levels correlated weakly with soil humic and fulvic acid concentrations, but 
strongly correlated with the ratio between these acids. Families of grasses (Poaceae) dominated the surveyed communities and accumulated most $\mathrm{C}$ and least $\mathrm{N}$, while Fabaceae and forbs accumulated most $\mathrm{N}$ and lignin and least $\mathrm{C}$.

\section{Acknowledgements}

Research activities were part funded by FP7 COST Action ES0805.

\section{References}

Allan, E., Bosdorff, O., Dormann, C.F., Prati, D. et al. (2014). Interannual variation in land-use intensity enhances grassland multidiversity. Proc. Natl. Acad. Sci. USA, 111(1), 308-313. DOI: 10.1073/pnas.1312213111.

Arponen, A., Heikkinen, R.K., Paloniemi, R., Pöyry, J., Similä, J. \& Kuussaari M. (2013). Improving conservation planning for semi-natural grasslands: Integrating connectivity into agri-environment schemes. Biol. Conserv., 160, 234-241. DOI: 10.1016/j.biocon.2013.01.018.

Bloom, A.J., Chapin, F.S. \& Mooney H.A. (1985). Resource limitation in plants - an economic analogy. Ann. Rev. Ecol. Syst., 16, 363-392. DOI: 10.1146/annurev.es.16.110185.002051.

Bošnjak, K., Knežević, M., Leto, J., Vranić, M., Perčulija, G. \& Kutnjak H. (2006). Productivity and sward composition of semi-natural pasture under different $\mathrm{N}$ fertilizing regimes. In J. Lloveras, A. Gonzáles-Rodríguez, O. Vásquez-Yanez, J. Pineiro, O. Santamaria, L. Olea \& M.J. Poblaciones (Eds.), Sustainable grassland productivity (pp. 83-85). Proceedings of the $21^{\text {st }}$ general meeting of the European Grassland Federation. Badajoz: Artes Gráficas Marcipa.

Bray, J.R. (1963). Root production and the estimation of net productivity. Can. J. Bot., 41, 65-72. DOI: 10.1139/ b63-007.

Bullock, J.M., Pywell, R.F, Burke, J.W. \& Walker K.J. (2001). Restoration of biodiversity enhances agricultural production. Ecol. Lett., 4, 185-189. DOI: 10.1046/j.1461-0248.2001.00215.x.

Cardinale, B.J., Wright, J.P., Cadotte, M.W., Carroll, I.T., Hector, A., Srivastava, D.S., Loreau, M. \& Weis J.J. (2007). Impacts of plant diversity on biomass production increase through time because of species complementarity. Proc. Natl. Acad. Sci. USA., 104, 18123-18128. DOI: 10.1073/pnas.0709069104.

Česnulevičius, A., Ramonas, A. \& Valiūnas J. (2003). The correlation between geological substratum and landscape components in geomorphological micro-regions of Lithuania. Litosfera, 7, 127-133.

Daugèlienè, N. \& Butkute R. (2007). The productivity of long-term grassland as influenced by the variation of botanical groups of herbs under the conditions of different soil $\mathrm{pH}$ and fertilization (in Lithuania). ZemdirbysteAgriculture, 94, 84-95.

Dickson, T.L. \& Gross K.L. (2013). Plant community responses to long-term fertilization: changes in functional group abundance drive changes in species richness. Oecologia, 173(4), 1513-1520. DOI: 10.1007/s00442-0132722-8.

Eilts, J.A., Mittelbach, G.G., Reynolds, H.L. \& Gross K.L. (2011). Resource heterogeneity, soil fertility, and species diversity: effects of clonal species on plant communities. Am. Nat., 177(5), 574-588. DOI: 10.1086/659633.

Elgersma, A., Schlepers, H. \& Nassiri M. (2000). Interactions between perennial ryegrass (Lolium perenne L.) and white clover (Trifolium repens L.) under contrasting nitrogen availability: productivity, seasonal pattern of species composition, $\mathrm{N}_{2}$ fixation, $\mathrm{N}$ transfer and N recovery. Plant Soil, 221, 281-299. DOI: 10.1023/A:1004797106981.

Flombaum, P. \& Sala O.E. (2008). Higher effect of plant species diversity on productivity in natural than artificial ecosystems. Proc. Natl. Acad. Sci. USA, 105, 6087-6090. DOI: 10.1073/pnas.0704801105.

Gastal, F. \& Lemaire G. (2002). N uptake and distribution in crops: an agronomical and ecophysiological perspective. J. Exp. Bot., 53(370), 789-799. DOI: 10.1093/jexbot/53.370.789.

Grasslands of Lithuania (2006). Final report on National Grassland Inventory 2002-2005. Lithuanian Fund for Nature and Royal Dutch Society for Nature Conservation.

Gustavsson, E. (2007). Grassland plant diversity in relation to historical and current land use. Doctoral thesis, Swedish University of Agricultural Sciences, Uppsala.

Hovd, H. (2008). Extensively managed strips in intensively cultivated grasslands as possible contributors to increased plant species richness. Acta Agric. Scand. Sec. B, Soil Plant Sci., 58, 43-50. DOI: 10.1080/09064710601160276.

Janssens, F., Tallowin, J.R.B., Bakker, J.P., Bekker, R.M., Fillat, F. \& Oomes M.J.M. (1998). Relationships between soil 
chemical factors and grassland diversity. Plant Soil, 202, 69-78. DOI: 10.1023/A:1004389614865.

Kadžiulienè, Ž. \& Kadžiulis L. (2007). Nitrogen accumulation and efficiency in herbage depending on legume species in grassland sward. Biologija, 53(1), 54-59. DOI: 10.6001/biologija.v53i1.718.

Karpavičienè, B. \& Marcinkonis S. (2009). Meadow floristic composition in a non-point pollution zone of a swinebreeding complex (in Lithuania). Zemdirbyste-Agriculture, 96, 165-175.

Klimas, E. \& Baležentienè L. (2008). Fertilization impact on natural and sown grassland floristic improvement. Zemes Ukio Mokslai, 15, 41-45.

Liu, H.S., Li, F.M. \& Xu H. (2004). Deficiency of water can enhance root respiration rate of drought-sensitive but not drought-tolerant spring wheat. Agric. Water Manag., 64, 41-48. DOI: 10.1016/S0378-3774(03)00143-4.

Maire, V., Gross, N., Da Silveira Pontes, L., Picon-Cochard, C. \& Soussana J. (2009). Trade-off between root nitrogen acquisition and shoot nitrogen utilization across 13 co-occurring pasture grass species. Funct. Ecol., 23, 668-679. DOI: 10.1111/j.1365-2435.2009.01557.x.

Marcinkonis, S. (2007). Transition paths of former low productive agricultural land. Ekologija, 53(3), 30-33. DOI: 10.6001/ekologija.v53i3.1167.

McCrea, A.R., Trueman, I.C. \& Fullen M.A. (2004). Factors relating to soil fertility and species diversity in both semi-natural and created meadows in the West Midlands of England. Eur. J. Soil Sci., 55, 335-348. DOI: 10.1111/j.1365-2389.2004.00606.x.

Mills, A., Moot, D.J. \& Jamieson, P.D. (2009). Quantifying the effect of nitrogen on productivity of cocksfoot (Dactylis glomerata L.) pastures. Eur. J. Agron., 30, 63-69. DOI: 10.1016/j.eja.2008.07.008.

Öster, M. (2006). Biological diversity values in semi-natural grasslands: indicators, landscape context and restoration. Doctoral dissertation, Stockholm, Sweden.

Pace, P.F., Cralle, H.T., El-Halawany, S.H.M., Cothren, J.T. \& Scott A. (1999). Drought-induced changes in shoot and root growth of young cotton plants. Journal of Cotton Science, 3, 183-187. http://journal.cotton.org

Pärtel, M., Bruun, H.H. \& Sammul M. (2005). Biodiversity in temperate European grasslands: origin and conservation. In R. Lillak, R. Viiralt, A. Linke \& V. Geherman (Eds.), Integrating efficient grassland farming and biodiversity (pp. 1-14). Proceedings of the $13^{\text {th }}$ International Occasional Symposium of the European Grassland Fedaration Tartu.

Plantureux, S., Peeters, A. \& McCracken D. (2005). Biodiversity in intensive grasslands: effects of management, improvement and challenges. Agronomy Research, 3, 153-164.

Redman, M. (2002). Agriculture and environment in Malta, Latvia and Lithuania. National Report. London: IEEP. http://www.ieep.org.uk

Sendžikaitè, J. \& Pencekauskienė D. (2003). Structure and productivity of sown meadow communities on the Central Lithuanian Plain (on the model of Graisupis Experimental Field Station). Botanica Lithuanica. 9, 337-356.

Schläpfer, B. \& Ryser P. (1996). Leaf and root turnover of three ecologically contrasting grass species in relation to their performance along a productivity gradient. Oikos, 75, 398-406. DOI: $10.2307 / 3545880$.

Sulzer, W., Gspurning, J., Magnes, M., Pink R., Muick, M. \& Sengl P. (2013). Biotope mapping of extensive/intensive grassland supported by remote sensing and mobile GIS in Eastern Styria (Austria). Ekológia (Bratislava), 32(4), 335-344. DOI: 10.2478/eko-2013-0030.

Tilman, D., Reich, P.B., Knops, J., Wedin, D., Mielke, T. \& Lehman C. (2001). Diversity and productivity in a longterm grassland experiment. Science, 294, 843-845. DOI: 10.1126/science.1060391.

Waide, R.B., Willig, M.R., Steiner, C.F., Mittelbach, G., Gough, L., Dodson, S.I., Juday, G.P. \& Parmenter R. (1999). The relationship between productivity and species richness. Annu. Rev. Ecol. Syst., 30, 257-300. DOI: 10.1146/ annurev.ecolsys.30.1.257.

Wilson, C., Undi, M., Tenuta, M., Wittenberg, K.M., Flaten, D., Krause, D.O., Entz, M.H., Holley, R. \& Ominski K.H. (2009). Pasture productivity, cattle productivity and metabolic status following fertilization of a grassland with liquid hog manure: A three-year study. Can. J. Anim. Sci.. 90(2), 233-243. DOI: 10.4141/CJAS09037.

Zableckienè, D. \& Butkute B. (2006). Yield and feeding value of grazing swards with different botanical composition (in Lithuania). Veterinarija ir Zootechnika, 36(58), 84-90. 